\title{
Implementation, Stakeholders' Participation and Sustainability of Public Projects in Kenya: A Conceptual Framework
}

\author{
N. Gicovi Njue ${ }^{1}$, A. Sabina Mulwa ${ }^{1}$, D. Ndunge Kyalo ${ }^{1} \&$ J. Mwaura Mbugua ${ }^{1}$ \\ ${ }^{1}$ Department of Open Learning, University of Nairobi, Kenya \\ Correspondence: N. Gicovi Njue, Department of Open Learning, University of Nairobi, Kenya. Tel: 254-7-2372- \\ 0958. Email: nicnjueg@yahoo.com
}

$\begin{array}{lrr}\text { Received: July 1, } 2021 & \text { Accepted: July 19, } 2021 & \text { Online Published: July 23, } 2021 \\ \text { doi:10.5539/jsd.v14n4p100 } & \text { URL: https://doi.org/10.5539/jsd.v14n4p100 }\end{array}$

\begin{abstract}
Many public organizations are faced with numerous constraints that limit optimum and sustainable realization of their long-term aspirations. Similarly, implementation of public projects is often hampered by rigid bureaucracies that often edge out good opportunities for public and stakeholders to contribute to sustainable decisions. In response, most of innovative public organizations are quickly formulating guidelines and procedures for integrating stakeholders in project decisions making for greater responsiveness and sustainability. However, many public projects never live to full realization of sustainable changes. Questions arise on the strategies employed to ensure inclusive stakeholder participation in sustainable project implementation. Whereas the conceptualization of project sustainability is abstractly defined in literature, studies have linked implementation strategies to sustainability outcomes. But projects are implemented in very dynamic contexts. Hence the need for case-based evaluation of how project implementation connects to sustainability. Despite the indications that stakeholder participation can play a dualistic role in project sustainability, past empirical studies have assessed stakeholders` participation from linear perspective. This study seeks to fill the knowledge gaps by investigating the interaction between stakeholders ' participation and the relationship between implementation and sustainability of public projects in Kenya.
\end{abstract}

Keywords: stakeholders` participation, project implementation, project sustainability

\section{Introduction}

\subsection{Background}

As government and public sector organizations seek to optimize realization of their policy aspirations through projects, there is growing adoption of project management methodologies, tools and techniques. Frustrated by the structural limitations, governments and public organizations all over the world are shifting to agile project management that allow for integration of processes and practices that adapt to the dynamic environment. This innovative strategy helps to overcome implementation uncertainties and challenges for more effective and responsive projects (Caliste, 2012). Amongst the factors with potential impacts on project implementation discourse is the changing stakeholders' need and interest. Regardless the nature or type of project, effective participation of stakeholders is not only a good practice in project management but also a requirement by the international standards for project management (Anton \& Stellingwerf, 2013; PMI, 2017). This is because frustrated stakeholders are likely to disown and reject project. As a result, project is likely to face turbulence as stakeholders withdraw their commitment and support henceforth posing serious threat to project sustainability.

All over the world, there is emerging trend in the adoption of public or stakeholders' participation policies in project development. For example, in United States project designers and managers are adopting systematic approaches that integrate stakeholders in decision making during project implementation (Langrafe, Barakat, Stocker \& Boaventura, 2020). In Asia, interests of stakeholders are addressed through collaborative engagements in the project cycle so as to promote sustainable impacts (Verral, 2020; Panneer et al., 2021). In Africa, governments are instituting appropriate public participation laws and guidelines in order to optimize stakeholders' capacities in bolstering sustainability of projects. For instance, public organizations are employing structured cross-sectoral and multi-stakeholders' approaches for integrating governments, international players, donors, business players, third-sector and local communities in sustainable decision making (Goll, Uhl, \& Zwiers, 2019). In East African region, governments are incorporating sustainable development strategies through stakeholder 
involvement with an aim of promoting long-term positive impacts of investment projects (Warinda, Nyariki, Wambua, Muasya \& Hanjira 2020). In Kenya, participation of public and stakeholders in development projects is not only anchored in the Constitution of Kenya 2010 but also guided by public participation Act of 2019 . Furthermore, stakeholders' mapping and partnerships is recognized as the ultimate vehicle towards sustainable realization of the Kenya's Vision 2030 and Sustainable Development Goals (Government of Kenya, 2019). This indicates that stakeholders' participation is a core element for sustainable impacts.

\subsection{Problem Statement}

In Kenya, stakeholder and public participation in public projects is necessitated by law. However, reports and studies have attributed poor delivery of government projects to inadequate stakeholder participation (IGRCK, 2019; IISS, 2018; Musau \& Kirui, 2018; Matu, Kyalo, Mbugua \& Mulwa 2020; Moulid, Muchelule \& Wechuli, 2021). While successful projects are implemented collaboratively, not all projects are effective in rendering sustainable impacts. For instance, the International Monetary Fund (2020) alleges that half of all Kenya`s big four projects have stalled due to over ambitions and manipulations so as to appease electorates. In support, Onyango (2020) attributes failure of Kenya's mega projects to poor implementation decisions that fail to adopt collaborative sustainability decision making. Examples of stalled projects include the construction of Arror-Kimwarer dam projects at cost of US\$ 630Million (Rutto, 2020) and Galana Kulalu irrigation project at Cost of US\$4.5Billion (Odhiambo, 2019). Other projects that have stalled indefinitely includes the Universal Health Coverage, the National Housing Development Fund and the Nairobi Commuter Railway project (Odhiambo, 2020). Since 2002, all stalled public projects in Kenya are valued at US\$ 90Billion (Guguyu, 2021). According to the World Bank Group and Kenyan National Assembly Budget Committee of $8^{\text {th }}$ June 2021, some of the stalled projects is due to breach of guidelines that require diligence decisions in stakeholder collaboration. Another cause of stall is poor participatory planning methods and accountability (Government of Kenya, 2021). While fast-tracking is recommended to revive the stalled projects in order to avoid increased cost of completion and legal compensation claims by contractors if projects are cancelled (Government of Kenya, 2021), participatory review of the stalled projects could give stakeholders an opportunity to contribute to sustainable resolutions for greater socioeconomic development per the aspiration of Kenya's The Vision 2030. Thus, this study presents a conceptual framework for the interaction between stakeholders' participation with project implementation in solving sustainability issues of public project in Kenya.

\subsection{Research Objective}

To investigate how stakeholder participation mediates and moderates the relationship between implementation and sustainability of public projects in Kenya.

\subsection{Research Hypotheses}

$\mathbf{H}_{01}$ : There is no significant relationship between implementation and sustainability of public projects in Kenya.

H02: There is no significant mediation of stakeholder participation on the relationship between implementation and sustainability of public projects in Kenya

H03: There is no significant moderation of stakeholder participation on the relationship between implementation and sustainability of public projects in Kenya

\section{Literature Materials}

\subsection{Implementation and Sustainability of Projects}

Implementation is defined as the actualization of project plans through mobilization of resources, plans and schedules so as to realize the stated goals (Meredith \& Mantel, 2009). PMI (2017) explores project implementation as the art of coordinating peoples' effort, resources, processes and controlling change factors so as to deliver the desired outcomes. Evaluation and assignment of measures of project implementation is more complex due to the dynamic contexts in which projects operate. One factor contributing to this complexity is diverse views and perspectives of managers in managing change (San Cristóbal, Carral, Diaz, Fraguela \& Iglesias 2018). However, Katona (2019) and Petitjean (2016) proposes a framework of assessing project implementation from the aspects of meeting goals, innovativeness, success, efficiency and customer satisfaction. Kardes (2020) reiterates effectiveness and efficiency is a reliable parameter for evaluating project implementation. Further, Istikomah et al. (2020; Sieberhagen \& Cloete, 2012) proposes that appropriation of resources, application of processes and responsiveness of outputs as the overall indicators to evaluation of project implementation. It implies that the choice of indictors for assessing project implementation is context based.

In literature, the term suitability is fluidly defined which in turn confounds its measurement. However, Blewitt 
(2015) explores sustainability for the holistic perspective of interdependence between economic, social and ecological. Lynn and Kahle (2014) simplifies sustainability as the care between generations. The United Nation Brundtland Commission views sustainability as the ability of present generation to safeguarding the needs of future generation as it satisfies own. According to Project Management Institute (PMI, 2017), project sustainability is contextualized as an integration of processes and procedures that transforms project into a commercial business case in order to meet stakeholders needs without compromising the needs of future generations. The capacity of project organization to continue delivering the expected impacts is sustainability (PMI, 2017). It implies that sustainability of comprised of three pillars namely: economy, society and environment. The definition project sustainability by PMI draws out the following aspects: stakeholder involvement, partnerships, market linkage and diversification of project opportunities.

Public projects are the projects owned or operated by government and they serve to advance government policies and strategies in meeting the needs of the general public (Gasic, 2016). Examples of public projects includes but not limited to public infrastructures like roads, railways, dams, bridges and public facilities like stadiums, hospitals, schools, leisure centers among others. Sustainability of public projects have received criticism due to budgeting issues, poor feasibility, poor coordination, poor management skills, lack of flexibility and accountability, lack stakeholder participation, political manipulations, lack of commercial viability and unresponsiveness (Ahlawat \& Sin; 2019; Nguyen, 2017; Olele, 2016). Increased number of stakeholders raises conflicts of interests in public projects thus posing dereliction to sustainability. This calls for appropriate sustainability strategies for guaranteeing desired impacts. Hence it is proposed as follows.

Proposition One: There is no significant relationship between implementation and sustainability of public projects in Kenya.

\subsection{Stakeholder Participation, Implementation and Sustainability of Public Projects}

Stakeholder is an institution, individual or group of people with interests or affected by the implementation of a given project (Schwermer et al., 2020). Stakeholders in public projects may be beneficiaries or citizens, donors, contractors, suppliers, evaluators, county government, media, etc. Project stakeholders have dynamic needs, interests and expectations to the project (Kilonzo, 2017 Schwermer, Barz \& Zablotski, 2020). The way managers allow stakeholders to participate and integrate needs during implementation determines both performance and sustainability of projects. Thus effective stakeholder participation processes should allow parties with stake to freely express their views, opinions, thoughts, ideas on the most sustainable project decisions (Ratnayake, Wickramaarachchi. \& Wattege 2017). Stakeholder participation in project implementation is not only a matter of global concern but also a requirement by the international community to ensure collaborative and integrated problem resolution (ICAT, 2019). Participatory approaches have differing contribution to project sustainability. For instance, stakeholders' diversity in terms personality, demographic and functional diversity has differing effects on project responsiveness and sustainability (van Knippenberg \& Schnippers, 2007; Stokes, Kneale \& Sutcliffe, 2019). Varying propositions attribute stakeholders' interest on the project sustainability. For instance, Hugue, (2020) suggests that that stakeholder interests hinders project sustainability. In contrast, Carrillo (2020) and Hunjra, Verhoeven and Zureigat (2007) consider stakeholder's interests as compatible contributors to project sustainability. This inconsistency complicates stakeholder integration decisions. Since participation in public projects is a collective decision-making responsibility, project ownership is perceived to have a significant contribution to the project sustainability (Joensuu et al., 2019; Kalu, \& Rugami, 2021).

Uzochukwu et al. (2020) claim that actors' capacities like experiences, skills, resources and expertise are critical determinants of project sustainability. Thus, investing on stakeholders` capacities eases implementation challenges leading to better chances of project sustainability. Socio-cultural dynamics of stakeholders are also important predictor of project sustainability (Ali et al., 2020). However, the dynamics of stakeholders` capacity makes it more difficult to predict the contribution of stakeholders to project sustainability. This leads to the following propositions.

Proposition Two: There is no significant mediation of stakeholder participation on the relationship between implementation and sustainability of public projects in Kenya

Proposition Three: There is no significant moderation of stakeholder participation on the relationship between implementation and sustainability of public projects in Kenya 
Table 1. Summary of knowledge gap

\begin{tabular}{|c|c|c|c|}
\hline Authors & Research Area & Knowledge Gap & Focus of Current Study \\
\hline $\begin{array}{l}\text { Toljaga-Nikoli'c, Todorovi'c, } \\
\text { Dobrota, Obradovi'c and } \\
\text { Obradovi'c (2020), Kuchta and } \\
\text { Mrzygłocka-Chojnacka (2020), } \\
\text { Ozumba Ozumba, Tasmiyah, } \\
\text { Zanoxolo, and Nikiwe (2020) }\end{array}$ & $\begin{array}{l}\text { Project } \\
\text { implementation and } \\
\text { sustainability }\end{array}$ & $\begin{array}{l}\text { The results } \text { are not } \\
\text { generalizable in } \\
\text { different across } \\
\text { different project } \\
\text { contexts }\end{array}$ & $\begin{array}{lr}\text { Relationship between } \\
\text { implementation } \\
\text { sustainability of public } \\
\text { projects }\end{array}$ \\
\hline $\begin{array}{l}\text { Matu et al. (2020), } \\
\text { Wamugu and Ogollah (2017), } \\
\text { Magassouba, Tambi, Alkhlaifat, } \\
\text { and Abdullah. } \\
\text { Uzochukwu (2020), }\end{array}$ & $\begin{array}{l}\text { Stakeholders' } \\
\text { participation } \\
\text { project } \\
\text { identification, } \\
\text { planning, } \\
\text { sustainability } \\
\text { projects }\end{array}$ & $\begin{array}{l}\text { Stakeholder } \\
\text { participation is } \\
\text { assumed to act only } \\
\text { as an independent } \\
\text { variable }\end{array}$ & $\begin{array}{lr}\text { Mediation of } & \text { stakeholder } \\
\text { participation } & \text { on } \\
\text { relationship } & \text { between } \\
\text { implementation } & \text { and } \\
\text { sustainability of public } \\
\text { projects variable }\end{array}$ \\
\hline $\begin{array}{l}\text { Ochunga and Awiti (2017), } \\
\text { Makau, Mackenzi and Nicole } \\
\text { (2018), } \\
\text { Okul and Nyonje (2020), } \\
\text { Suleiman (2018), } \\
\text { Kamau (2017) }\end{array}$ & $\begin{array}{l}\text { Stakeholders' } \\
\text { participation } \\
\text { execution, } \\
\text { monitoring } \\
\text { evaluation } \\
\text { sustainability } \\
\text { projects }\end{array}$ & $\begin{array}{l}\text { Stakeholder } \\
\text { participation is } \\
\text { assumed to act only } \\
\text { as an independent } \\
\text { variable }\end{array}$ & $\begin{array}{l}\text { To examine how } \\
\text { stakeholder participation } \\
\text { moderates interplay } \\
\text { between implementation } \\
\text { and sustainability of } \\
\text { public projects variable }\end{array}$ \\
\hline
\end{tabular}

\subsection{Theoretical Framework}

Sustainability theory and stakeholder theory anchor this study. Sustainability theory was advanced by Felix Ekard in 2009 to set ground for the creation of impactful and universally accepted practices for protecting the longtime socioeconomic gains of project (Ekardt, 2014). Thus sustainability theory states that a society derives impactful and long-lasting gains if there exists justice between now and future generations without exploitation. Sustainability theory is anchored on the principle of public participation for sustainable decision making (Enders \& Remig, 2015). In this study, sustainability theory supports that stakeholders` participation in implementation decisions leads to more sustainable impacts.

Developed by Freeman in 1980s, stakeholders' theory states that projects optimize positive impacts from stakeholders ' participation (Freeman, 1984). Stakeholders' theory emphasizes on finest utilization of stakeholders` potentials for greater ownership and sustainability. As such, project managers should be in forefront when addressing stakeholders needs, interests, disputes and expectations. Consequently, stakeholder theory is used to explain that effective implementation of public projects need to integrate stakeholders in making sustainable decisions. Stakeholder participation promotes transparency, equity and fairness, openness and ownership to public projects.

\subsection{Conceptual Framework}

Figure 1 presents the flow of research variables for the study to investigate how stakeholder participation mediates and moderates the relationship between implementation and sustainability of public projects in Kenya. 
Figure 1 Conceptual Framework Independent Variable

\section{Dependent Variable}

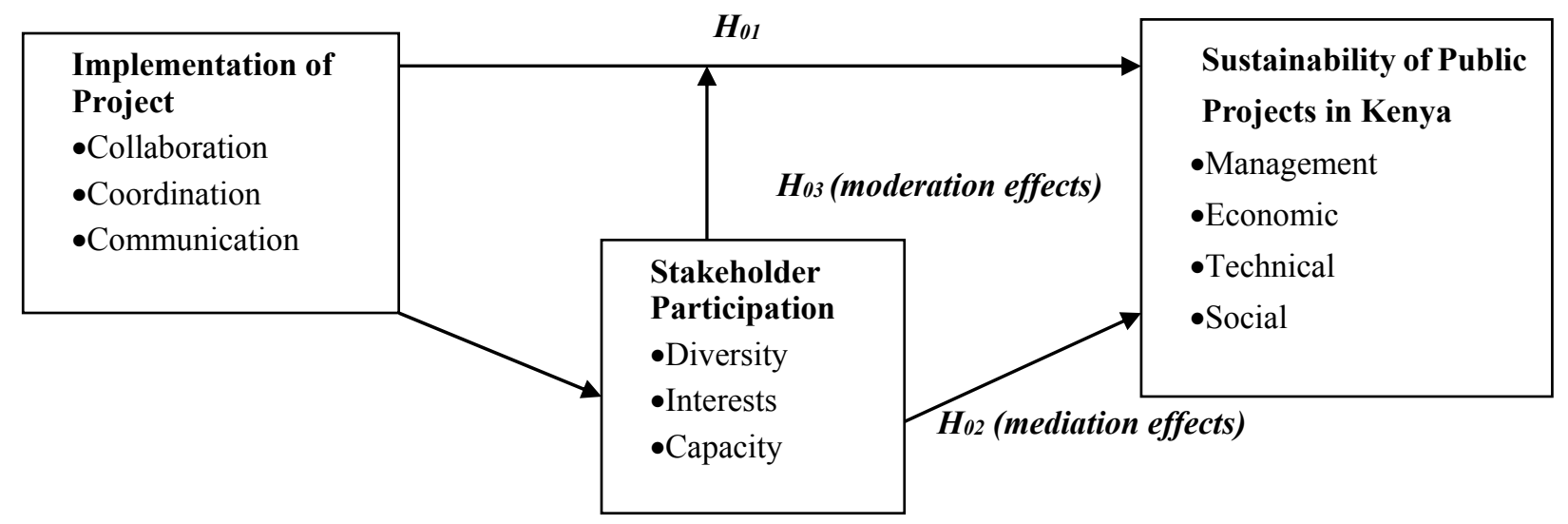

Figure 1. Conceptualization for mediation and moderation of stakeholder participation on the relationship between implementation and sustainability of public project Kenya

From figure 1, the dependent variable is sustainability of public projects in Kenya. The independent variable is conceptualized as implementation of project. Stakeholder participation is perceived to have dualistic interaction with the relationship between implementation and sustainability of public projects. In one hand, stakeholder participation is perceived to mediate the relationship between implementation and sustainability of public projects. In the other hand, stakeholders' participation is perceived to regulate or catalyze the relationship between implementation and sustainability of public projects in Kenya.

\section{Discussion}

This paper has presented a conceptual framework for a study to investigate the interaction between stakeholders' participation and relationship between implementation and sustainability of public projects in Kenya. Sustainability of development projects is one of the principles of good governance and a requirement in the Sustainable Development Goals. Similarly, stakeholder participation is a project knowledge management area that guarantees sustainable project outcomes. In this paper, stakeholder participation is perceived to mediate and moderate the association between implementation and sustainability of public projects. Project implementation is conceptualized as a predictor variable with linear relationship with the outcome variable namely: sustainability of public projects.

\section{Conclusion}

From the discussions, it can be concluded that researchers need to actualize this conceptual framework in order to generate an empirical evidence to conclude the interaction between stakeholders' participation and the relationship between implementation and sustainability of public projects.

\section{Acknowledgement}

The authors acknowledge the support extended by the Jomo Kenyatta Memorial Library of the University of Nairobi for allowing ease access of literature materials through remote access.

\section{References}

Ahlawat, A., \& Singh, G. (2019). Challenges in Public Private Partnership Infrastructure Project- A Case Study. Conference Paper May 2019.

Ali, T. S., Karmaliani, R., Khuwaja, H. M. A., Shah, N. Z., Wadani, Z. H., Aijaz, S., \& Kulane, A. (2020). Community stakeholders' views on $\mathrm{r}$ educing violence against women in Pakistan. BMC Womens Health. https://doi.org/10.1186/s12905-020-00961-3

Anton, Z., \& Stellingwerf, R. (2013). ISO 21500 Guidance on project management - A Pocket Guide, Van Haren Publishing, May 2013, Netherlands, front cover.

Blewitt, J. (2015). Understanding sustainable development (2nd ed.). Landon: Routledge. https://doi.org/10.4324/9781315886459

Caliste, A. L. E. (2012). The project management project-challenges in the public sector. Paper presented at 
PMI ${ }^{\circledR}$ Global Congress 2012-North America, Vancouver, British Columbia, Canada. Newtown Square, PA: Project Management Institute.

Gasik, S. (2016). Are public projects different form projects in other sectors? Preliminary results of empirical research. Procedia Computer Science, 100(2016), 399-406. https://doi.org/10.1016/j.procs.2016.09.175

Goll, E., Uhl, A., \& Zwiers, J. (2019). Sustainable development in the Middle East and North Africa (MENA) Region. Mapping Geopolitical shifts, regional order and domestic transformations, Berlin.

Government of Kenya. (2019). Implementation of the Agenda 2030 for sustainable development in Kenya. Government printer.

Government of Kenya. (2021). The budget and appropriation committee report of estimates of revenue and expenditure for the financial year 2021/2022. Government Printer.

Guguyu, O. (2021). Stalled projects in Uhuru, Kibaki eras cross Sh9trn. The Business Daily, $25^{\text {th }}$ June, 2021.

Hugue, A. S. (2020). Infrastructure, Political Conflict, and Stakeholder Interests: The Case of a Public-Private Partnership in Bangladesh. Case Report. https://doi.org/10.1177/1087724X19895281

Hunjra, A. I., Verhoeven, P., \& Zureigat, Q. (2020). Capital Structure as a Mediating Factor in the Relationship between Uncertainty, CSR, Stakeholder interest and Financial Performance. Journal of risk financial management, 13(117), 2-18. https://doi.org/10.3390/jrfm13060117

Intergovernmental Relations Committee of Kenya. (IGRCK, 2019). The status of public participation in national and county governments. Office printer, Kenya.

International Institute for Strategic Studies. (IISS, 2018). Lack of Public Participation Impedes Effective PolicyMaking and Implementation in Kenya.

International Monetary Fund. (2020). Half of all public projects in Kenya have stalled. Business daily newspaper of $17^{\text {th }}$ January, 2020.

Istikomah., K., M., \& Wardiah, D. (2020). An Evaluation of Literacy Program, For Improving Students' Achievement. International Journal of Progressive Sciences and Technologies (IJPS), 20(1), 26-32. Retrieved from http://ijpsat.ijsht-journals.org

Kalu, C., \& Rugami, J. (2021). Stakeholder Involvement and Infrastructure Projects Implementation at Kenya Ports Authority. International Journal of Business Management, Entrepreneurship and Innovation, 3(1), 7890. https://doi.org/10.35942/jbmed.v3i1.166

Kardes, S. (2020). Digital literacy in early childhood. Inonu University Journal of the Faculty of Education, 21(2), 827-839.

Katona, V. (2019). Role and Positioning of Reward Based Crowdfunding in the Funding of Technological Innovation Projects View- point of Entrepreneurial Financing Experts. Vezetéstudomány, 50(5), 13-24. https://doi.org/10.14267/VEZTUD.2019.05.02

Kilonzo, R., \& George, V. (2017). Sustainability of Community Based Water Projects: Dynamics of Actors' Power Relations: Journal of Sustainable Development, 10(6), 79-86. https://doi.org/10.5539/jsd.v10n6p79

Kuchta, D., \& Mrzygłocka-Chojnacka, J. (2020). An Approach to Increase the Sustainability of Projects and their Outcomes in Public Sector through Improving Project Definition. Sustainability, 12, 4804. https://doi.org/10.3390/su12124804

Langrafe, T. D. F., Barakat, S. R., Stocker, F., \& Boaventura, J. M. G. (2020). A stakeholder theory approach to creating value in higher education institutions. The Bottom Line, 33(4), 297-313. https://doi.org/10.1108/BL03-2020-0021

Lynn, R., \& Kahle, E. G. (2014). Communicating Sustainability for the Green Economy. New York: M.E. Sharpe. https://doi.org/10.4324/9781315705491

Magassouba, S. M., Tambi, A. M. B. A., Alkhlaifat, B. I., \& Abdullah, A. A. B. (2019). Influence of Stakeholders Involvement on Development Project Performance in Guinea. International Journal of Academic Research in Business and Social Sciences, 9(1), 1111-1120. https://doi.org/10.6007/IJARBSS/v9-i1/5513

Makau, J. N., Mackenzi, I. O. \& Nicole, D. (2018). The effect of stakeholders' participation on project monitoring and evaluation. The Strategic Journal of Business \& Change Management, 5(4), 2222-2229.

Matu, J., Kyalo, D., Mbugua, J., \& Mulwa, A. (2020) Stakeholder Participation in Project Planning: Prerequisite 
to Effective Completion of Urban Road Transport Infrastructure Projects in Kenya. Journal of Building Construction and Planning Research, 8, 73-91. https://doi.org/10.4236/jbcpr.2020.81006

Meredith, J. R., \& Mantel, S. J. (2009). Project Management, a Managerial Approach (7th ed.). Washington D.C USA, John Wiley \& Sons, Inc.

Moulid, H. M., Muchelule Y. W., \& Wechuli, W. T. (2021). Influence of stakeholders' management on performance of Coast Development Authority projects in Kenya. The Strategic Journal of Business \& Change Management, 8(2), 158-177.

Musau, P. M., \& Kirui, C. (2018). Project management practices and implementation of government projects in Kenya, case of Machakos County government. International Academic Journal of Information Sciences and Project Management, 3(2), 58-79.

Nguyen, D. A. (2017). Improving Public-Private Partnership Contracts through Risk Characterization. Contract Mechanisms, and Flexibility, pp.1-216. Retrieved from https://www.pwc.in/assets/pdfs/publications2012/the-road-ahead-highways-ppp

Ochunga, F. O., \& Awiti, L. H. (2017). Influence of Stakeholders` participation on Sustainability of Community Development Projects Implemented by Plan International in Homa Bay Town Sub-County, Kenya. International Journal of Academic Research in Business and Social Sciences, 7(4), 375-400. https://doi.org/10.6007/IJARBSS/v7-i4/2816

Odhiambo, M. (2019). Sh580 million to clear Galana Kulalu bushes. The Star Newspaper, 22 ${ }^{\text {nd }}$ May, 2019

Odhiambo, M. (2020). Uhuru legacy projects abandoned as funds reallocated to Covid-19. The Star Newspaper, $22^{\text {nd }}$ April, 2020

Okul, E. O., \& Nyonje, R. O. (2020). Examining stakeholder involvement in the evaluation process for program improvement. International Journal of Research in Business and Social Sciences, 9(5), 179-191. https://doi.org/10.20525/ijrbs.v9i5.835

Olele, C. A. (2016) The Challenges of Public Private Partnership (PPP) Projects in a Developing Country: The Case Study of the Lekki Toll Road Infrastructure Project in Lagos. PM World Journal, 5(10). Retrieved from http://pmworldjournal.net/wpcontent/uploads/2016/10/pmwj51-Oct2016-Olele-challenges-of-ppp-projectsindeveloping-country-featured-paper.pdf

Ozumba, A., Ozumba, A. Tasmiyah, C., Zanoxolo, B., \& Nikiwe, M. (2020). Sustainability in Project Management Practice. Conference: EPPM COnference - 2018At: Cape Town, South Africa.

Panneer, S., Kantamaneni, K., Pushparaj, R. R. B., Shekhar, S., Bhat, L., \& Rice, L. (2021). Multistakeholder Participation in Disaster Man.agement-The Case of the COVID-19 Pandemic. Healthcare, 9, 203. https://doi.org/10.3390/healthcare9020203

Petitjean, M. (2017). What explains the success of reward-based crowdfunding campaigns as they unfold? Evidence from the French crowdfunding platform KissKissBankBank. Finance Research Letters. https://doi.org/10.2139/ssrn.3769118

Project Management Institute. (PMI, 2017). A Guide to the Project Management Body of Knowledge (PMBOK Guide) (6th ed.). Newtown Square, PA.

Ratnayake., R., Wickramaarachchi., N., \& Wattege., P. (2017). Urban water body recreational development and revitalizing program in Sri Lanka: public perception and willingness to pay. Bhumi. The Planning Research Journal, 5(2). https://doi.org/10.4038/bhumi.v5i2.30

Rutto, S. (2020). Nothing going on at Arror and Kimwarer. The Standard Newspaper, $31^{\text {st }}$ December 2020.

San Cristóbal, J. R., Carral, L., Diaz, E., Fraguela, J. A., \& Iglesias, G. (2018). Complexity and Project Management: A General Overview. Complexity, 1-10. https://doi.org/10.1155/2018/4891286

Schwermer, H., Barz, F., \& Zablotski, Y. (2020). A Literature Review on Stakeholder Participation in Coastal and Marine Fisheries. Earth System Research and Sustainability, University of Hamburg Germany, Hamburg, German. https://doi.org/10.1007/978-3-030-20389-4_2

Sieberhagen, E., \& Cloete, L. (2012). The evaluation of a digital information literacy program. SA Jnl Libs \& Info Sci, Special Issue. https://doi.org/10.7553/80-2-33

Stokes, K., Kneale, D., \& Sutcliffe, K. (2019). Title: Diversity in reviewers: diverse researcher perspectives in systematic reviews may help to reduce potential researcher bias and improve reporting. The Department of 
Health and Social Care Policy Reviews Facility- a collaboration between three centers of excellence

Toljaga-Nikoli'c, D., Todorovi'c, M., Dobrota, M., Obradovi'c, T., \& Obradovi'c, V. (2020). Project Management and Sustainability: Playing Trick or Treat with the Planet. Sustainability, 12, 8619. https://doi.org/10.3390/su12208619

Uzochukwu, B. S. C., Okeke, C., O’Brien, N., Ruiz, F., Sombie, I., \& Hollingwo, S. (2020). Health technology assessment and priority setting for universal health coverage: a qualitative study of stakeholders' capacity, needs, policy areas of demand and perspectives in Nigeria. Globalization and Health, 16-58. https://doi.org/10.1186/s12992-020-00583-2

van Knippenberg, D., \& Schnippers, M. C. (2007). Work group diversity". Annual Review of Psychology, 58, 515541. https://doi.org/10.1146/annurev.psych.58.110405.085546

Varral, M. (2020). ASEAN'S ways to sustainable development. KPMG, Australia.

Wamugu, J. W. \& Ogollah, K. (2017). Role of stakeholders` participation on the performance of constituency development fund projects in Mathira East constituency in Kenya. International Academic Journal of Information Sciences and Project Management, 2(1), 104-125.

Warinda, E., Nyariki, D. M., Wambua, S., Muasya, R. M., \& Hanjira, M. A. (2020). Sustainable Development in East Africa: impact evaluation of regional agricultural development projects in Burundi, Kenya, Rwanda, Tanzania and Uganda. Natural Resources Forum, 44(1). https://doi.org/10.1111/1477-8947.12191

\section{Copyrights}

Copyright for this article is retained by the author(s), with first publication rights granted to the journal.

This is an open-access article distributed under the terms and conditions of the Creative Commons Attribution license (http://creativecommons.org/licenses/by/4.0/). 